\title{
PENENTUAN PENERIMA PINJAMAN KOPERASI MEKAR SURYA KARANGANYAR MENGGUNAKAN METODE TECHNIQUE FOR ORDER PREFERENCE BY SIMILARITY OF IDEAL SOLUTION
}

\author{
Insania Istiqomah ${ }^{1)}$; Kustanto ${ }^{2}$; Bebas widada ${ }^{3)}$ \\ ${ }^{1,3)}$ Program Studi Sistem Informasi, STMIK Sinar Nusantara \\ ${ }^{2)}$ Program Studi Teknik Informatika, STMIK Sinar Nusantara \\ 1)istiqomahinsania@gmail.com; ${ }^{21}$ kustanto@sinus.ac.id; ${ }^{3)}$ bbswdd@sinus.ac.id
}

\begin{abstract}
The problems arise in the form of less objective decision-making and require a long time for selection and there is no computerized system that supports the prioritization of loan recipients. The purpose of this study was to overcome the problem determination of loan recipients by providing objective assessments to prospective loan recipients at the Cooperative Mekar Surya Karanganyar using the technique for order preference by similarity of ideal solution method. Loan determination applications use the Visual Basic programming language. Research methods include data collection and analysis and system design. The formulation of this research problem covers how the loan determination at the Cooperative Mekar Surya Karanganyar uses the technique for order preference by similarity of ideal solution method and how to build a loan determination application system using the technique for order preference by similarity of ideal solution method using the Visual Basic programming language. Based on the test results by comparing the determination of customer loan recipients in the Mekar Surya Cooperative with the calculation of the TOPSIS method proves the application of determining the loan recipient has good performance.
\end{abstract}

Keywords: Technique for order preference by similarity of ideal solution, Determination of loan recipients, Cooperative

\section{PENDAHULUAN}

Perbankan merupakan bidang yang sangat berperan dalam perkembangan bisnis saat ini, dan salah satu kegiatan dalam perbankan yang menjadi sasaran pelaku bisnis untuk masyarakat, salah satunya yaitu koperasi simpan pinjam. Koperasi simpan pinjam "Koperasi Mekar Surya" merupakan salah satu koperasi simpan pinjam yang memberikan solusi dalam membantu penyediaan dan untuk berbagai keperluan secara cepat dan proses pinjaman yang mudah. Sebagai lembaga bisnis bidang perbankan, Koperasi Mekar Surya memiliki produk usaha yaitu simpanan dan pinjaman. Dimana didalam produk usaha pinjaman mendukung masyarakat untuk menerima pembiayaan guna mendirikan usaha mikro, usaha kecil dan usaha menengah. Dengan adanya produk usaha pinjaman, diharapkan dapat meringankan masyarakat dalam membuka suatu usaha.

Masalah yang ada pada Koperasi Mekar Surya dalam produk usaha pinjaman adalah membutuhkan waktu yang lama untuk penyeleksiannya dan belum ada sistem aplikasi yang mendukung untuk penentuan prioritas penerima pinjaman. Untuk mengatasi masalah tersebut maka dibutuhkan suatu sistem pendukung keputusan yang dapat memberikan penilaian yang real dan objektif kepada para calon penerima pinjaman. Karena pada penilaian ini menggunakan perhitungan berdasarkan kriteria-kriteria calon penerimaan pinjaman dengan sistem perankingan. Dalam sistem pendukung keputusan ini dihitung dengan menggunakan metode technique for order preference by similarity of ideal solution.

Sudah banyak metode yang digunakan dalam menerapkan sistem pendukung keputusan seperti yang telah dilakukan oleh beberapa peneliti sebelumnya yakni Sistem Pendukung Keputusan Penjurusan Siswa SMA N 1 Kawedanan Dengan Metode TOPSIS[1], Sistem Pendukung Keputusan Penilaian Kelayakan Pinjaman dengan Menggunakan Metode Simple Additive Weighting di Koperasi Roda Sejahtera Semarang[2], Sistem Pendukung Keputusan Penentuan Penerima Pinjaman Modal Dana Bergulir Koperasi Simpan Pinjam Pada Diskoperindag Kabupaten Serang Menggunakan Metode TOPSIS[3], Sistem Pendukung Keputusan Penentuan Penerima Pinjaman Usaha (Studi Kasus: Adira Finance Kediri)[4]. 
Berdasarkan kasus tersebut maka, pada penelitian ini mengangkat judul Penentuan Pinjaman Koperasi Mekar Surya Karanganyar Menggunakan Metode Technique For Order Preference By Similarity Of Ideal Solution. Hasil akhir dari penelitian ini adalah memberikan penilaian yang real dan objektif kepada para calon penerimaan pinjaman. Pada penilaian ini menggunakan perhitungan berdasarkan kriteria-kriteria calon penerima pinjaman dengan sistem perankingan. Penggunaan metode technique for order preference by similarity of ideal solution untuk mencari solusi atau alternatif yang dipilih yaitu penerima pinjaman. Penentuan penerima pinjaman koperasi mekar surya karanganyar menggunakan metode technique for order preference by similarity of ideal solution ini yang menjadi tujuan dari penelitian ini..

\section{TINJAUAN PUSTAKA}

Beberapa penelitian yang telah dilakukan berhubungan dengan sistem pendukung keputusan menjadi referensi dalam penulisan penelitian ini. Dalam penelitian ini peneliti menggunakan penelitian terdahulu sebagai acuan untuk menyelesaikan penelitian ini. Penelitian terdahulu memudahkan peneliti dalam menentukan langkah-langkah yang sistematis untuk penyusunan penelitian dari segi teori maupun konsep. Sehingga dapat digunakan sebagai acuan dan referensi untuk memudahkan peneliti dalam membuat penelitian ini. Adapun analisa 10 (sepuluh) penelitian terdahulu yang berkaitan dan sejenis dalam bentuk metode penelitiannya.

Implementasi pembuatan Sistem Pendukung Keputusan Penjurusan Siswa SMA N 1 Kawedanan dengan Metode Technique For Order Preference By Similarity Of Ideal Solution. telah selesai dibuat. Namun, hasil pengujian validitas, terdapat perbedaan angka, dikarenakan pembulatan bilangan desimal antara perhitungan sistem dan perhitungan manual [1].

Sistem pendukung keputusan penilaian kelayakan kredit pada Koperasi Roda Sejahtera dengan menggunakan Metode Simple Additive Weighting dapat memberikan informasi kepada manajer dengan hasil perhitungan kriteria yang diperoleh. Namun, dalam penelitian ini dapat dikembangkan dengan menambahkan menu yang mencakup seluruh prosedur perkreditan yang ada seperti kapasitas melunasi kredit, penagihan kredit dan lain-lain, sehingga program dapat dipergunakan secara optimal [2].

Sistem pendukung keputusan penentuan penerima pinjaman modal koperasi simpan pinjam pada Diskoperindag Kabupaten Serang ini, untuk melakukan perhitungan penentuan penerima pinjaman modal dengan hasil perankingan dan status "diterima" atau "ditolak" sesuai rentang nilai telah berhasil di bangun. Namun, ketelitian dalam menginput data juga sangat diperlukan agar data yang direkam merupakan salinan data dari dokumen atau sumber [3].

Sistem pendukung keputusan penentuan penerima kredit usaha dapat membantu pihak perusahaan Adira dalam menentukan siapa pemohon kredit yang layak menerima kredit atau tidak dengan sistem yang terkomputerisasi sehingga proses pengambilan keputusan lebih efisien, hemat waktu dan hemat biaya. Namun, di dalam penelitian ini tidak menghasilkan hasil keluaran berupa laporan, sehingga hanya menampilkan hasil perhitungan akhir [4].

Metode Technique For Order Preference By Similarity Of Ideal Solution.yang digunakan dalam studi kasus karyawan terbaik dapat diselesaikan dengan baik sehingga memudahkan dalam mendukung keputusan pemilihan karyawan terbaik. Namun, masih perlu dikembangkan lagi dengan menambahkan fungsionalitas perhitungan berat badan yang optimal. Sehingga tidak perlu dilakukan berulang kali dalam proses perhitungan berat badan [5].

Metode Technique For Order Preference By Similarity Of Ideal Solution. diterapkan untuk menentukan prioritas Kualitas Rumah Susun tidak sehat, dari hasil perhitungan dinyatakan alternatif ke-2 dengan nilai preferensi 1 merupakan prioritas utama untuk Kualitas Rumah Susun tidak sehat. Dari hasil perhitungan metode Technique For Order Preference By Similarity Of Ideal Solution. dapat menjadi masukan bagi dinas kesehatan 
terkait untuk menindaklanjuti prioritas rumah tidak sehat [6].

Kombinasi metode AHP- Technique For Order Preference By Similarity Of Ideal Solution. dapat digunakan untuk memecahkan masalah penyeleksian nasabah, hasil perhitungan menunjukkan bahwa kriteria yang paling diprioritaskan adalah kriteria kemampuan membayar kembali dibandingkan dengan kriteria lainnya seperti tanggungan keluarga, jangka waktu dan nilai jaminan. Namun, di dalam penelitian ini tidak menghasilkan hasil keluaran berupa laporan, sehingga hanya menampilkan hasil perhitungan akhir [7].

Dalam kasus ini metode Fuzzy Tsukamoto dapat membantu Koperasi Sejahtera dalam melakukan perhitung nilai besaran pinjaman yang diberikan kepada pengusaha UKM yang mengajukan pinjaman. Besaran pinjaman ditentukan oleh 4 parameter yaitu besaran omset, lama perusahaan berdiri dan nilai nominal jaminan. Namun, di dalam jurnal tidak menjelaskan hasil dari implementasi dari aplikasi sistem pendukung keputusan penentuan kelayakan kredit pinjaman UKM di Koperasi Sejahtera [8].

Memudahkan pihak bank dalam pengambilan keputusan penerimaan debitur untuk mengajukan kredit diperlukan Aplikasi Sistem Pendukung Keputusan. Dengan menerapkan metode Technique For Order Preference By Similarity Of Ideal Solution. dapat menghasilkan laporan data debitur yang akurat sehingga membantu manager dalam menentukan penerima pengajuan kredit pada Swamitra KSP Intranz. Namun, di dalam jurnal tidak menjelaskan tampilan implementasi dari Laporan yang di hasilkan aplikasi [9].

Sistem pendukung keputusan kelayakan penerimaan kredit pada koperasi sekawan dapat mempercepat proses pemberian kredit bagi pemohon yang sesuai dengan kriteria yang diberikan oleh koperasi sekawan abadi sejati. Sistem yang dibuat mengurangi kesalahan dalam memberikan kredit. Dengan adanya aplikasi ini membuktikan bahwa metode weighted product dapat di implementasikan kedalam sistem untuk menguji kelayakan pemberian kredit. Namun, perlu dikembangkan dengan penambahan kriteria, dengan penambahan menu bobot kriteria [10].

Beberapa penelitian tersebut peneliti menyimpulkan bahwa ada perbedaan di setiap penelitian tersebut diantaranya perbedaan kriteria yang digunakan dalam jurnal. Perbedaan kriteria tersebut membuat adanya perbedaan maupun metode serta tujuan dalam masing masing jurnal berbeda. Sehingga, berdasarkan kasus di atas maka, pada penelitian ini penulis mengangkat judul tentang Penentuan Prioritas Penerima Pinjaman Menggunakan Metode Technique For Order Preference By Similarity Of Ideal Solution di Koperasi Mekar Surya Karanganyar. Hasil akhir dari penelitian ini adalah memberikan penilaian yang real dan objektif kepada para calon penerimaan pinjaman. Pada penilaian ini menggunakan perhitungan berdasarkan kriteria-kriteria calon penerima pinjaman dengan sistem perankingan. Penggunaan metode Technique For Order Preference By Similarity Of Ideal Solution. untuk mencari solusi atau alternatif yang dipilih yaitu penerima pinjaman.

\section{METODE PENELITIAN}

Tahapan penulis dalam melakukan penelitian untuk mendapatkan data yang lengkap dan akurat, sehingga sebagai pelengkap sistem yang dibuat. Adapun data yang dibutuhkan berasal dari lokasi penelitian, data primer dan data sekunder. Dari data tersebut di lakukan pengumpulan data dengan cara yaitu wawancara, pengamatan dan studi pustaka. Sedangkan dalam metode perancangan sistem penulis membuat beberapa tahap yang terdiri dari Context Diagram, Hierarki Input Proses Output, Diagram Arus Data, Desain Database, Desain Input Output, dan Implementasi Sistem, serta Pengujian Sistem menggunakan pengujian validitas.

\section{HASIL DAN PEMBAHASAN}

Dalam pembahasan menguraikan mengenai diagram alir sistem, perancangan sistem, desain sistem, desain database, desain antarmuka, implementasi antarmuka dan pengujian. 


\section{Analisa Masalah Dengan Metode} Technique For Order Preference By Similarity Of Ideal Solution.

Penulis mengambil studi kasus penentuan prioritas penerima pinjaman di Koperasi Mekar Surya, dengan sampel 3 data nasabah. Calon penerima yang mengajukan proposal pinjaman akan digunakan sebagai inputan nilai pada aplikasi yang akan dibuat. Kriteria dan bobot masing - masing kriteria yang menjadi pertimbangan, yang ditunjukkan pada Tabel 1 .

Tabel 1. Bobot preferensi

\begin{tabular}{|c|c|c|}
\hline Kriteria & Cost / Benefit & $\begin{array}{c}\text { Bobot } \\
\text { Preferensi } \\
\text { (W) }\end{array}$ \\
\hline Karakter & Benefit & 4 \\
\hline Jaminan & Benefit & 3 \\
\hline Penghasilan & Benefit & 4 \\
\hline Kondisi Ekonomi & Benefit & 3 \\
\hline Pekerjaan & Benefit & 5 \\
\hline Pinjaman & Benefit & 4 \\
\hline Jangka Waktu & Benefit & 4 \\
\hline
\end{tabular}

Pada perhitungan ini sistem pendukung keputusan menggunakan metode TOPSIS, data-data yang diperlukan diantaranya alternative-alternatif keputusan, kriteria-kriteria penilaian, dan bobot keputusan. Dalam ketiga kasus ini akan di ambil 1 penerima pinjaman. Dari ketiga nasabah tersebut dimasukkan ke dalam tabel, seperti ditunjukkan pada Tabel 2.

Tabel 2 Contoh kasus calon penerima pinjaman

\begin{tabular}{|l|c|c|c|}
\hline \multirow{2}{*}{ Kriteria } & \multicolumn{3}{|c|}{ Calon Penerima Pinjaman } \\
\cline { 2 - 4 } & $\begin{array}{c}\text { Peminjam } \\
\text { Karakter } \\
\text { (C1) }\end{array}$ & $\begin{array}{c}\text { Peminjam } \\
\text { Kurang }\end{array}$ & $\begin{array}{c}\text { Peminjam } \\
\mathbf{3}\end{array}$ \\
\hline $\begin{array}{l}\text { Jaminan } \\
\text { (C2) }\end{array}$ & $\begin{array}{c}\text { Sertifikat } \\
\text { Rumah }\end{array}$ & $\begin{array}{c}\text { BPKB } \\
\text { Mobil }\end{array}$ & $\begin{array}{c}\text { Bilyet } \\
\text { Simpanan }\end{array}$ \\
\hline $\begin{array}{l}\text { Penghasilan } \\
\text { (C3) }\end{array}$ & 3.450 .000 & 3.600 .000 & 4.200 .000 \\
\hline $\begin{array}{l}\text { Kondisi } \\
\text { Ekonomi } \\
\text { (C4) }\end{array}$ & 1.941 .333 & 1.274 .000 & 2.305 .333 \\
\hline $\begin{array}{l}\text { Pekerjaan } \\
\text { (C5) }\end{array}$ & PNS & Swasta & Wiraswasta \\
\hline $\begin{array}{l}\text { Pinjaman } \\
\text { (C6) }\end{array}$ & 32.000 .000 & 21.000 .000 & 38.000 .00 \\
\hline $\begin{array}{l}\text { Jangka } \\
\text { Waktu (C7) }\end{array}$ & 24 bulan & 24 bulan & 24 bulan \\
\hline
\end{tabular}

Menentukan rating kecocokan setiap alternatif pada setiap kriteria. Penentuan tersebut dibuat berdasarkan suatu tingkat kepentingan kriteria berdasarkan nilai bobot yang telah ditentukan. Rating kecocokan bobot setiap kriteria, dari sangat rendah memiliki nilai 0 , rendah memiliki nilai 0,25 , sedang memiliki nilai 0,5 , dan tinggi memiliki nilai 0,75 , serta sangat tinggi memiliki nilai 1 . Ditunjukkan pada Tabel 3.

Tabel 3 Rating kecocokan alternatif

\begin{tabular}{|c|c|c|c|}
\hline \multirow{2}{*}{ Kriteria } & \multicolumn{3}{|c|}{ Calon Penerima Pinjaman } \\
\cline { 2 - 4 } & Peminjam & Peminjam & Peminjam \\
& $\mathbf{1}$ & $\mathbf{2}$ & $\mathbf{3}$ \\
\hline C1 & 0 & 1 & 0,75 \\
\hline C2 & 0,75 & 0,25 & 1 \\
\hline C3 & 0,5 & 0,5 & 0,75 \\
\hline C4 & 0,75 & 0,5 & 1 \\
\hline C5 & 0,75 & 0,25 & 0,5 \\
\hline C6 & 0,5 & 0,25 & 0,5 \\
\hline C7 & 1 & 1 & 1 \\
\hline
\end{tabular}

Membuat matriks keputusan ternormalisasi

$$
R_{i j}=\frac{x_{i j}}{\sqrt{\sum_{i=1}^{m} x_{i j}^{2}}}
$$

Dimana $x_{i j}$ adalah bobot dari masing masing kriteria dan $\sqrt{\sum_{i=1}^{m} x_{i j}^{2}}$ adalah akar dari jumlah kuadrat tiap kriteria.

Hasil matriks keputusan ternormalisasi ditunjukkan pada Tabel 4.

Tabel 4 Matriks ternormalisasi

\begin{tabular}{|l|l|l|l|}
\hline \multirow{2}{*}{ Kriteria } & \multicolumn{3}{|l|}{ Calon Penerima Pinjaman } \\
\cline { 2 - 4 } & Peminjam1 & Peminjam2 & Peminjam3 \\
\hline Karakter & 0 & 0,8 & 0,6 \\
\hline Jaminan & 0,588348405 & 0,196116135 & 0,784464541 \\
\hline Penghasilan & 0,48507125 & 0,48507125 & 0,727606875 \\
\hline $\begin{array}{l}\text { Kondisi } \\
\text { Ekonomi }\end{array}$ & 0,624695048 & 0,468521286 & 0,624695048 \\
\hline Pekerjaan & 0,801783726 & 0,267261242 & 0,534522484 \\
\hline Pinjaman & 0,666666667 & 0,333333333 & 0,666666667 \\
\hline $\begin{array}{l}\text { Jangka } \\
\text { Waktu }\end{array}$ & 0,577350269 & 0,577350269 & 0,577350269 \\
\hline
\end{tabular}

Membuat

matriks keputusan ternormalisasi terbobot berdasarkan rumus: 


$$
y_{i j=} W_{i} r_{i j}
$$

Dimana $W_{i}$ adalah bobot dari kriteria, dan $r_{i j}$ adalah hasil bagi antara bobot tiap kriteria dengan hasil akar pangkat tiap kriteria. Hasil perhitungan matriks ternomalisasi ditunjukkan pada Tabel 5.

Tabel 5. Matriks ternormalisasi terbobot

\begin{tabular}{|l|c|c|c|}
\hline \multirow{2}{*}{ Kriteria } & \multicolumn{3}{|c|}{ Calon Penerima Pinjaman } \\
\cline { 2 - 4 } & Peminjam1 & Peminjam2 & Peminjam3 \\
\hline Karakter & 0 & 3,2 & 2,4 \\
\hline Jaminan & 1,765045216 & 0,588348405 & 2,353393622 \\
\hline Penghasilan & 1,940285 & 1,940285 & 2,9104275 \\
\hline $\begin{array}{l}\text { Kondisi } \\
\text { Ekonomi }\end{array}$ & 1,874085143 & 1,405563857 & 1,874085143 \\
\hline Pekerjaan & 4,008918629 & 1,33630621 & 2,672612419 \\
\hline Pinjaman & 2,666666667 & 1,333333333 & 2,666666667 \\
\hline $\begin{array}{l}\text { Jangka } \\
\text { Waktu }\end{array}$ & 2,309401077 & 2,309401077 & 2,309401077 \\
\hline
\end{tabular}

Menentukan matriks solusi ideal positif dan matriks ideal negatif. Nilai yang paling mendekati 1, maka dipilih sebagai ideal positif sedangkan yang paling mendekati nilai 0 , maka dianggap sebagai ideal negatif.

$$
\begin{aligned}
& A^{+}=\max \left(y_{1}^{+}, y_{2}^{+}, \ldots, y_{n}^{+}\right) \\
& A^{-}=\min \left(y_{1}^{-}, y_{2}^{-}, \ldots, y_{n}^{-}\right)
\end{aligned}
$$

Dari rumus tersebut maka diperoleh tabel solusi ideal positif dan solusi ideal negatif. Ditunjukkan pada tabel 6.

Tabel 6. Matriks solusi ideal positif dan matriks solusi ideal negatif

\begin{tabular}{|l|c|c|}
\hline \multicolumn{1}{|c|}{ Kriteria } & A+ & A- \\
\hline Karakter & 3,2 & 0 \\
\hline Jaminan & 2,353393622 & 0,588348405 \\
\hline Penghasilan & 2,9104275 & 1,940285 \\
\hline $\begin{array}{l}\text { Kondisi } \\
\text { Ekonomi }\end{array}$ & 1,874085143 & 1,405563857 \\
\hline Pekerjaan & 4,008918629 & 1,33630621 \\
\hline Pinjaman & 2,666666667 & 1,333333333 \\
\hline Jangka Waktu & 2,309401077 & 2,309401077 \\
\hline
\end{tabular}

Menentukan jarak antara nilai setiap alternatif dengan matriks solussi ideal positif dan matriks ideal negatif

$$
\begin{aligned}
& D_{i}^{+} \sqrt{\sum_{j=1}^{n}\left(y_{i j}-A_{i}^{+}\right)^{2} ; i=1,2, \ldots, m .} \\
& D_{i}^{-} \sqrt{\sum_{j=1}^{n}\left(y_{i j}-A_{i}^{-}\right)^{2} ; i=1,2, \ldots, m .}
\end{aligned}
$$

\section{Dimana :}

$D_{i}^{+}=$jarak antara nilai setiap alternatif dengan matriks solusi ideal positif
$D_{i}^{-}=$jarak antara nilai setiap alternatif dengan matriks solusi ideal negatif

$\mathrm{A}_{+}=$nilai solusi ideal positif

A- $=$ solusi ideal negatif

$\mathrm{y}=$ Rating bobot ternormalisasi

Dari rumus tersebut maka diperoleh tabel jarak solusi ideal positif dan jarak solusi ideal negatif. Ditunjukkan pada Tabel 7.

Tabel 7. Jarak solusi ideal positif dan matriks ideal negatif

\begin{tabular}{|c|c|c|c|}
\hline Jarak & Peminjam1 & Peminjam2 & Peminjam3 \\
\hline D+ & 3,395192236 & 3,632727378 & 1,557470477 \\
\hline D- & 3,244189036 & 3,2 & 3,687758851 \\
\hline
\end{tabular}

Menentukan nilai preferensi untuk setiap alternatif

$V_{i}=\frac{D_{i}^{-}}{D_{i}^{-}+D_{i}^{+}}$,dimana $i=1,2,3, \ldots m$.

Dimana :

$V_{i}=$ Nilai Preferensi

$\mathrm{D}+=$ Solusi Ideal Positif

D- = Solusi Ideal Negatif

Dari rumus tersebut maka diperoleh nilai preferensi. Ditunjukkan pada Tabel 8.

Tabel 8. Nilai preferensi

\begin{tabular}{|l|l|l|}
\hline \multicolumn{3}{|c|}{ Nilai Preferensi } \\
\hline \multirow{3}{*}{$V_{i}$} & 0,488628217 & Peminjam1 \\
\cline { 2 - 3 } & 0,468334213 & Peminjam2 \\
\cline { 2 - 3 } & 0,703069136 & Peminjam3 \\
\hline
\end{tabular}

Kemudian berdasarkan nilai $V_{i}$ yang didapat, dilakukan pengurutan dari yang terbesar sampai yang terkecil. Ditunjukkan pada Tabel 9.

Tabel 9. Hasil akhir

\begin{tabular}{|c|c|c|}
\hline \multicolumn{3}{|c|}{ Hasil Akhir } \\
\hline \multirow{3}{*}{$v$} & 0,703069136 & Peminjam1 \\
\cline { 2 - 3 } & 0,488628217 & Peminjam2 \\
\cline { 2 - 3 } & 0,468334213 & Peminjam3 \\
\hline
\end{tabular}

Dari nilai $V$ ini dapat dilihat bahwa $V_{i}$ memiliki nilai terbesar, sehingga dapat disimpulkan bahwa alternatif pertama yang akan lebih dipilih. Dengan kata lain, Lisa akan dipilih sebagai nasabah yang layak menerima pinjaman. Lisa layak menerima pinjaman, karena dalam contoh kasus hanya mengambil 
1 penerima, dari 3 nasabah yang mengajukan pinjaman.

\section{Context Diagram}

Context diagram dalam kasus ini menggambarkan sistem yang sedang berjalan pada penentuan penerima pinjaman di koperasi mekar surya karanganyar. ditunjukkan pada Gambar 1.

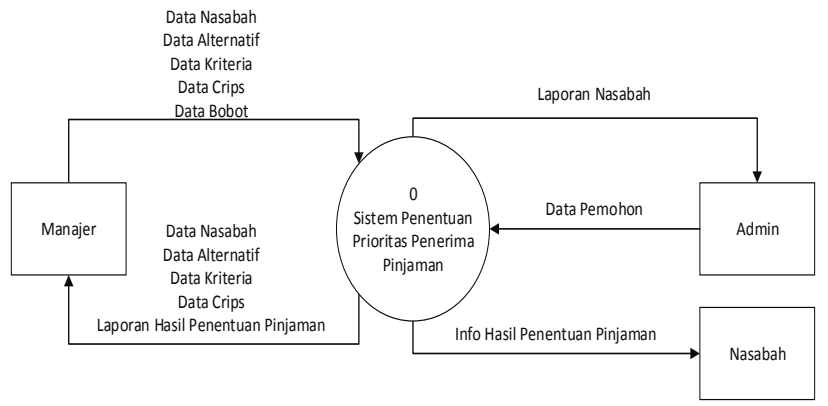

Gambar 1 Context diagram

Gambar 1 menjelaskan bahwa sistem terdiri dari 4 entitas yaitu administrator dan pemilik sebagai entitas internal serta pegawai dan nasabah sebagai entitas external.

\section{Entity Relationship Diagram (ERD)}

Entity Relationship Diagram (ERD) pada sistem penentuan penerima pinjaman di Koperasi Mekar Surya memiliki 5 entitas. Dari beberapa entitas tersebut membentuk suatu relasi antar entitas yang saling terhubung satu sama dengan lain dengan mempunyai foreign key. Ditunjukkan pada Gambar 2.

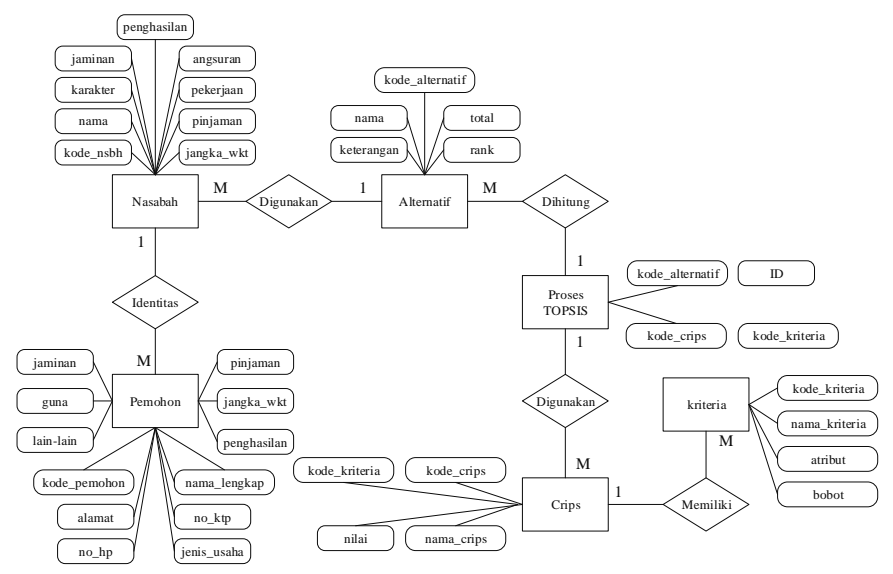

Gambar 2. Relasi antar tabel

\section{Implementasi Sistem}

Implementasi sistem dari penentuan penerima pinjaman di Koperasi Mekar Surya Karanganyar dengan menggunakan metode Technique for Order Preference by Similarity of Ideal Solution, sebagai berikut: a. Form Alternatif

Form alternatif digunakan untuk menambah data alternatif nasabah atau mengubah data alternatif nasabah yang akan diseleksi. Ditunjukkan pada Gambar 3.

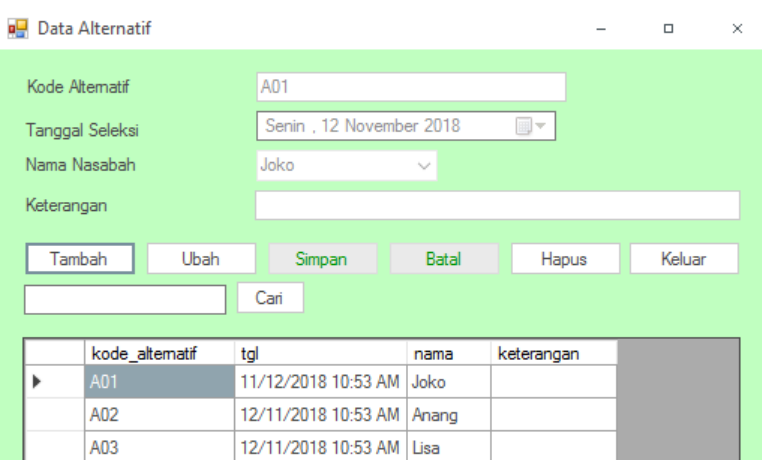

Gambar 3. Halaman alternatif

b. Form Kriteria

Form kriteria digunakan untuk menambah data kriteria atau mengubah data kriteria yang sudah ada. Ditunjukkan pada Gambar 4.

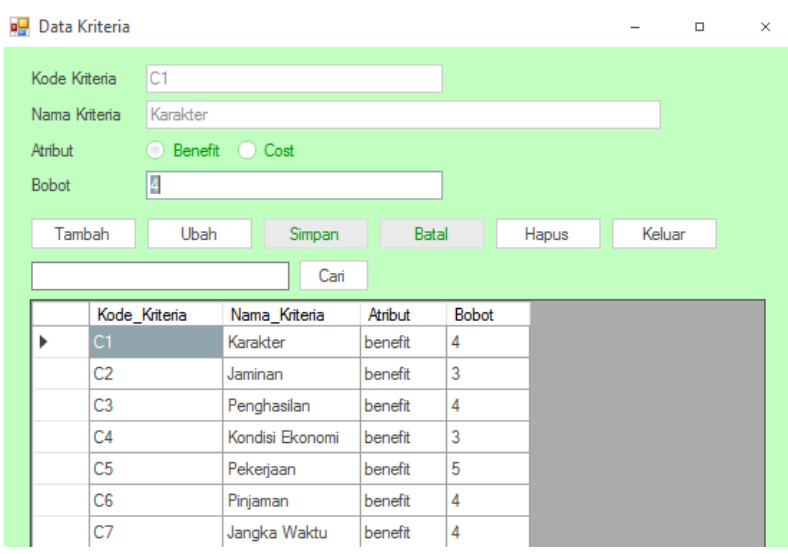

Gambar 4. Halaman kriteria

c. Form Crips

Form crips digunakan untuk menambah data nilai batas atau mengubah data nilai batas yang sudah ada. Ditunjukkan pada Gambar 5. 


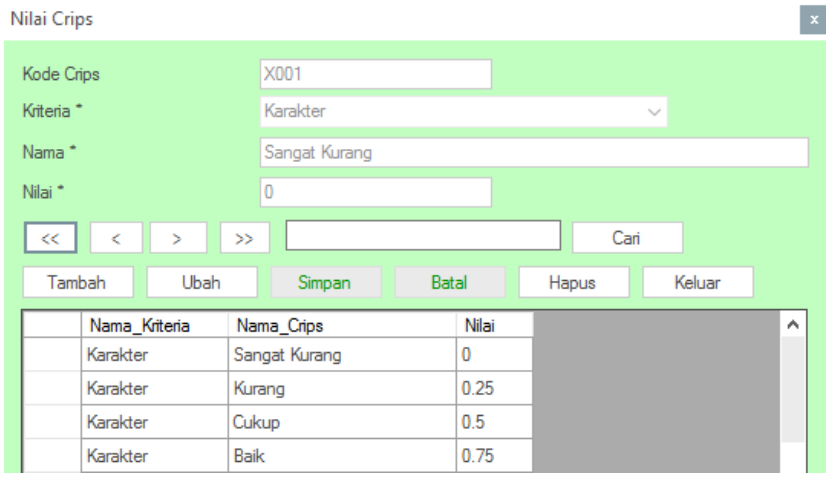

Gambar 5. Halaman crips

d. Form Nilai Bobot

Form nilai bobot berisi semua data nilai alternatif nasabah yang dipilih pegawai. Digunakan untuk menambahkan data nilai kriteria setiap alternatif nasabah. Ditunjukkan pada Gambar 6.

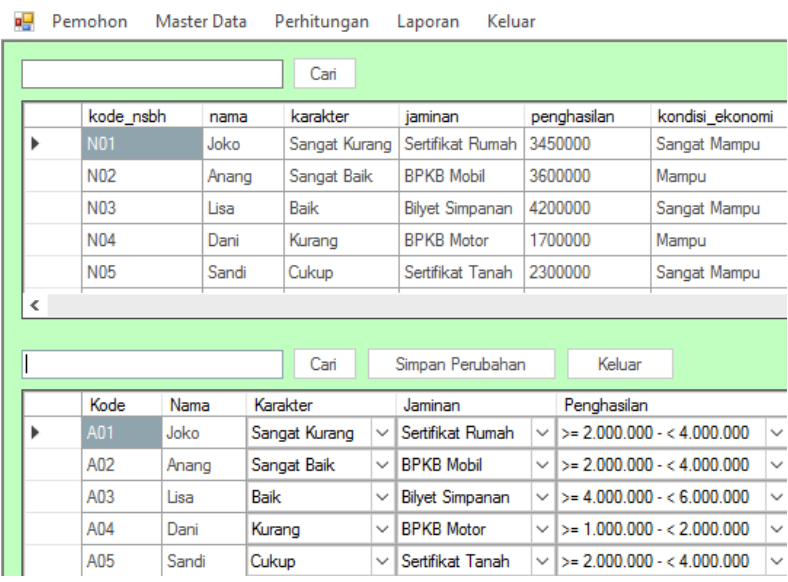

Gambar 6. Halaman nilai bobot

e. Form Perhitungan

Form perhitungan digunakan untuk mencari hasil seleksi. Pada tahap ini program menggunakan metode Technique for Order Preference by Similarity of Ideal Solution dalam prosesnya. Ditunjukkan pada Gambar 7.

\begin{tabular}{|c|c|c|c|c|c|c|c|c|c|}
\hline \multicolumn{2}{|c|}{ Cetak Hasil } & Keluar & & & & & & & \\
\hline \multicolumn{2}{|c|}{ Hasil Analisa } & Normalisasi & \multicolumn{2}{|c|}{ Normalisasi Terbobot } & \multicolumn{2}{|c|}{ Solusi Ideal } & Jarak Solusi & \multicolumn{2}{|c|}{ Hasil Akhir } \\
\hline & Kode & Nama & $\mathrm{C} 1$ & C2 & $\mathrm{C} 3$ & $\mathrm{C} 4$ & $\mathrm{C} 5$ & C6 & C7 \\
\hline \multirow[t]{3}{*}{ • } & $\mathrm{A} 01$ & Joko & 0 & 0.75 & 0.5 & 1 & 0.75 & 0.5 & 1 \\
\hline & $\mathrm{A} 02$ & Anang & 1 & 0.25 & 0.5 & 0.75 & 0.25 & 0.25 & 1 \\
\hline & $\mathrm{A} 03$ & Lisa & 0.75 & 1 & 0.75 & 1 & 0.5 & 0.5 & 1 \\
\hline
\end{tabular}

Gambar 7. Halaman tampilan proses seleksi

Untuk melihat hasil seleksi dengan menekan tombol hasil akhir. Kemudian akan muncul form hasil akhir. Setelah itu, menekan tombol cetak hasil untuk melihat laporan hasil seleksi. Ditunjukkan pada gambar 8.

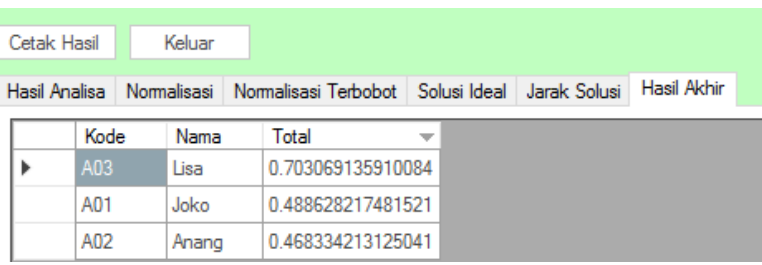

Gambar 8. Halaman tampilan hasil akhir

f. Laporan Hasil Seleksi

Laporan data hasil seleksi digunakan untuk melaporkan data hasil seleksi dengan menampilkan pilihan pencetakan ke layar atau ke printer sesuai kebutuhan. Ditunjukkan pada Gambar 9.

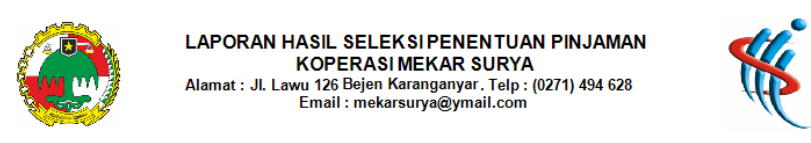

03 April 2019

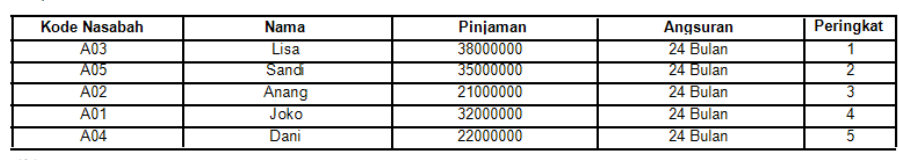

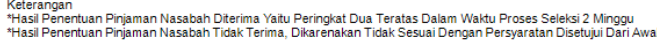

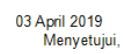

Gambar 9. Halaman laporan hasil seleksi

5. Pengujian Sistem

Pengujian Koperasi Mekar Surya dan pengujian metode Technique for Order Preference by Similarity of Ideal Solution Dilakukan dengan membandingkan antara cara penentuan penerima pinjaman nasabah di Koperasi Mekar Surya dengan perhitungan Metode Technique for Order Preference by Similarity of Ideal Solution. Di dalam pengujian sistem ini peneliti mengambil tiga contoh kasus. Dengan, contoh kasus sebagai berikut:

a. Pertama, nasabah bernama peminjam1 bekerja sebagai PNS memiliki penghasilan setiap bulan Rp. $\quad 3.450 .000,-$. Dilingkungan sekitar rumah beliau dikenal sangat buruk dalam pelunasan hutang. Beliau ingin meminjam uang sebesar Rp. 32.000.000,-. Dengan kesanggupan beliau mengangsur setiap bulan dengan jangka waktu selama 24 bulan. Beliau berada dalam kondisi ekonomi mampu. 
Dengan jaminan yang beliau berikan berupa sertifikat rumah.

b. Kedua, nasabah bernama Peminjam2 bekerja sebagai Swasta memiliki penghasilan setiap bulan Rp. $\quad 3.600 .000,-$. Dilingkungan sekitar rumah beliau dikenal sangat baik dalam pelunasan hutang. Beliau ingin meminjam uang sebesar Rp. 21.000.000,-. Dengan kesanggupan beliau mengangsur setiap bulan dengan jangka waktu selama 24 bulan. Beliau berada dalam kondisi ekonomi cukup. Dengan jaminan yang beliau berikan berupa BPKB Mobil.

c. Ketiga, nasabah bernama Peminjam3 bekerja sebagai Wiraswasta memiliki penghasilan setiap bulan Rp. 4.200.000,-Dilingkungan sekitar rumah beliau dikenal baik dalam pelunasan hutang. Beliau ingin meminjam uang sebesar Rp. 38.000.000,-. Dengan kesanggupan beliau mengangsur setiap bulan dengan jangka waktu selama 24 bulan. Beliau berada dalam kondisi ekonomi sangat mampu. Dengan jaminan yang beliau berikan berupa Bilyet Simpanan.

Pada penentuan pinjaman, ketiga nasabah memberikan surat permohonan pinjaman. Kemudian, dari surat permohonan tersebut ditindak lanjuti pihak koperasi bagian pinjaman. Tindak lanjut tersebut dengan melakukan survei berdasarkan kriteria 5C. Dari hasil survei tersebut pihak pengurus melakukan musyawarah bersama. Namun, dalam melakukan musyawarah membutuhkan waktu lama dan kurang objektif dalam pengambilam keputusan. Dari hasil musyawarah mendapatkan hasil berupa prioritas penerima pinjaman yang akan diberikan kepada nasabah. Dari hal tersebut timbul permasalahan berupa kurang objektif dalam pengambilan keputusan dan membutuhkan waktu yang lama untuk penyeleksiannya

Sedangkan, pada perhitungan sistem pendukung keputusan menggunakan metode Technique for Order Preference by Similarity of Ideal Solution di Koperasi Mekar Surya, calon penerima yang mengajukan surat permohonan pinjaman digunakan sebagai inputan nilai pada aplikasi yang dibuat.
Kemudian, menentukan bobot preferensi setiap kriteria. Dari bobot preferensi tersebut di lakukan perhitungan penentuan penerima pinjaman menggunakan metode Technique for Order Preference by Similarity of Ideal Solution.

Berdasarkan hasil perhitungan nilai $\mathrm{V}$ di Tabel 9 menunjukkan bahwa alternatif pertama lebih dipilih. Dengan kata lain, Lisa akan dipilih sebagai nasabah prioritas penerima pinjaman.

Dapat disimpulkan bahwa dalam penentuan penerima pinjaman di Koperasi Mekar Surya timbul permasalahan berupa kurang objektif dalam pengambilan keputusan dan proses membandingkan kriteria membutuhkan waktu lama. Sedangkan, penentuan prioritas penerima pinjaman menggunakan metode Technique for Order Preference by Similarity of Ideal Solution dengan kriteria yang telah disesuaikan dengan pengajuan pinjaman di Koperasi Mekar Surya menghasilkan sistem yang objektif sehingga dapat membantu dalam penentuan prioritas penerima pinjaman.

\section{Analisa Pengujian}

Analisa pengujian yang didapat dari pengujian penentuan penerima pinjaman nasabah di Koperasi Mekar Surya memiliki kesamaan dalam penentuan penerima pinjaman dengan metode Technique for Order Preference by Similarity of Ideal Solution. Namun, penentuan penerima pinjaman nasabah di Koperasi Mekar Surya, memakan waktu lebih lama berdasarkan dari hasil survei pihak pengurus melakukan musyawarah bersama. Dari hasil musyawarah mendapatkan hasil berupa layak dan tidaknya nasabah yang akan diberikan pinjaman.

Sedangkan perhitungan menggunakan metode Technique for Order Preference by Similarity of Ideal Solution, berdasarkan nilai rating tertinggi. Pada penilaian ini menggunakan perhitungan berdasarkan kriteria-kriteria calon penerimaan pinjaman dengan sistem perankingan. Sehingga, dapat memberikan penilaian yang real dan objektif kepada calon penerima pinjaman.

Berdasarkan hasil analisa dan hasil pengujian diatas membuktikan bahwa aplikasi penentuan penerima pinjaman dengan menggunakan metode Technique for Order Preference by Similarity of Ideal Solution memiliki kinerja yang baik, sehingga dapat diterapkan di Koperasi Mekar Surya Karanganyar untuk membantu pegawai bagian pinjaman untuk mengambil keputusan pada 
proses seleksi penentuan penerima pinjaman sesuai dengan kriteria.

\section{PENUTUP}

\subsection{Kesimpulan}

Berdasarkan hasil pembuatan aplikasi Penentuan Prioritas Penerima Pinjaman menggunakan Metode Technique For Order Preference By Similarity Of Ideal Solution di Koperasi Mekar Surya Karanganyar, dapat diambil kesimpulan sebagai berikut :

1. Telah dibangun aplikasi penentuan penerima pinjaman di Koperasi Mekar

Surya Karanganyar menggunakan Metode Technique for Order Preference by Similarity of Ideal Solution.

2. Masalah yang ada pada Koperasi Mekar Surya membutuhkan waktu yang lama dan kurang objektif dalam menentukan penyeleksian pinjaman. Dengan adanya penentuan prioritas penerima pinjaman yang telah dibangun dapat memberikan penilaian yang real dan objektif kepada calon penerima pinjaman.

3. Berdasarkan hasil pengujian dengan membandingkan antara penentuan penerima pinjaman nasabah di Koperasi Mekar Surya dengan perhitungan metode Technique for Order Preference by Similarity of Ideal Solution membuktikan aplikasi penentuan penerima pinjaman memiliki kinerja yang baik.

\subsection{Saran}

Adapun saran kedepan yang ingin peneliti sampaikan adalah metode Technique for Order Preference by Similarity of Ideal Solution bukan satu - satunya metode pengambilan keputusan yang digunakan, dalam memecahkan masalah multikriteria. Sehingga, dapat dikembangkan menggunakan metode lain. Sebagai pembanding untuk pengambilan keputusan, agar lebih baik dan lebih efisien.

Hasil dari penentuan prioritas penerima pinjaman sebaiknya hanya dijadikan sebagai alat bantu dalam mengambil keputusan sedangkan pengambilan keputusan tetap di tangan pengambil keputusan.

\section{DAFTAR PUSTAKA}

[1] A. S. Wicaksono, S. H. Fitriasih, and Kustanto, "Sistem Pendukung Keputusan Penjuran Siswa SMA N 1 Kawedanan Dengan Metode TOPSIS," J. Teknol. Inf. dan Komun. Sinar Nusant., vol. 5, no. 2, pp. 40-45, 2017.

[2] A. Riyantomo, N. E. Budiyanto, and A. Laksitasari, "Sistem Pendukung Keputusan Penilaian Kelayakan Kredit dengan Menggunakan Metode Simple Additive Weighting di Koperasi Roda Sejahtera Semarang," Momentum, vol. 14, no. 1, pp. 62-68, 2012.

[3] A. Triayudi and F. S. Hidayat, "Sistem Pendukung Keputusan Penentuan Penerima Pinjaman Modal Dana Bergulir Koperasi Simpan Pinjam Pada Diskoperindag Kabupaten Serang Menggunakan Metode TOPSIS," J. ProTekInfo, vol. 3, no. 1, pp. 49-54, 2016.

[4] Y. B. Utomo and J. Ipmawati, "Sistem Pendukung Keputusan Penentuan Penerima Kredit Usaha ( Studi Kasus: Adira Finance Kediri )," Citec J., vol. 3, no. 4, pp. 295-306, 2016.

[5] Jasri, D. Siregar, and R. Rahim, "Decision Support System Best Employee Assessments with Technique for Order of Preference by Similarity to Ideal Solution," Int. J. Recent Trends Eng. Res., vol. 03, no. 03, pp. 6-17, 2017.

[6] A. Aziz, "Decission Support System Menentukan Kualitas Rumah Susun Pada Pemda Pringsewu Menggunakan Metode Topsis," Konf. Mhs. Sist. Inf., vol. 6, no. 1, pp. 1-6, 2018.

[7] C. S. Aulia Putra Faza, "Implementasi Metode AHP-Topsis untuk Menentukan Kelayakan Pinjaman Modal (Studi Kasus Pada Koperasi Simpan Pinjam Jasa Pekalongan)," J. Inf. Syst., vol. 1, no. 1, 2016.

[8] A. Syafrianto, "Sistem Pendukung Keputusan Penentuan Kelayakan Kredit Pinjaman UKM di Koperasi Sejahtera," J. IIm. DASI Vol., vol. 16, no. 4, pp. 11-16, 2015.

[9] P. Mauliana, N. Hunaifi, and F. Wahyudi, "Sistem Pendukung Keputusan Penerimaan Debitur Menggunakan Metode TOPSIS (Studi Kasus: Swamitra KSP Intranz)," J. Infotronik, vol. 3, no. 1, pp. 15-20, 2018.

[10] R. Tamtoro and H. Heribertus, "Sistem Pendukung Keputusan Kelayakan 
Pemberian Kredit Pada Koperasi Simpan Pinjam Sekawan Dengan Menggunakan Metode Weighted Product," J. Inf. Syst., vol. 14, no. 1, pp. 1-11, 2015. 